\title{
Culture of Entrepreneurship in Public Universities of the Colombian Caribbean Region
}

\author{
Cielo Margarita Rodriguez Lopez ${ }^{1}$, Danny Daniel Lopez Juvinao ${ }^{2^{*}}$ and \\ Fabio Orlando Moya Camacho ${ }^{2}$ \\ 'EMPRENDEDORES, Universidad de La Guajira, Maicao, Colombia; cmrodriguez@uniguajira.edu.co \\ 2IPAITUG, Universidad de La Guajira, Riohacha, Colombia; dlopezj@uniguajira.edu.co, fmoya@uniguajira.edu.co
}

\begin{abstract}
Objectives: The main purpose of this article was to analyze the culture of entrepreneurship in public universities of the Colombian Caribbean region. Materials and Methods: A descriptive-analytical, transversal, non experimental and field-type of methodology was applied. The target population comprised the coordinators of the different agencies that deal with entrepreneurship in public universities in the departments belonging to the Colombian Caribbean region, to which a questionnaire was applied in order to measure the variable. Findings: It was concluded that an institutional educational project with vision and projection that anticipates changes, allows image positioning in terms of management and results with clearly significant and differentiating elements in order to promote a culture of entrepreneurship is required. Application/Improvements: Public policies of entrepreneurship were evaluated followed by a description of the missionary processes of the Caribbean Coast universities within the business culture, as well as the dimensions of the institutional management linked to entrepreneurship culture.
\end{abstract}

Keywords: Colombia, Culture of Entrepreneurship, Institutional Management, Missionary Processes, Public Policies, Public Universities

\section{Introduction}

Entrepreneurship implies to carry out a key function in economic and technical progress, in order to generate changes and welfare for humanity; depending to a certain extent on the quality and effectiveness of knowledge generation processes. In this regard, the existence of an entrepreneurship culture based on techno-scientific knowledge, the exploitation of research and development and innovation is fundamental, so that organizations, whatever their size and activity sector may be, can invigorate and evolve achieving a sustainable development.

In the university context, entrepreneurship has taken a stance in missionary functions of teaching, research and extension, as an important issue. Training in the different disciplines is not enough to perform successfully in a globalized economy, so it is necessary to offer alternatives of life for future professionals ${ }^{1}$.
Particularly in the case of Colombia, Law 1014 entered into force in 2006, by means of which the culture of entrepreneurship $^{2}$ is fostered. It provides the legal framework, definitions, guidelines and actors in the matter, such as the Ministry of Commerce, Industry and Tourism, which is currently responsible for the modernization of the public policy of entrepreneurship in the country. Among the actions carried out, there is an agreement signed with the Colombian Association of Universities $\left(\mathrm{ASCUN}^{3}\right.$ in Spanish), with the purpose of joining efforts to strengthen university entrepreneurship through extracurricular activities.

In this respect, it can be generated new training processes to link universities with public or private organizations through teaching, research and extension areas; while the processes of knowledge production serve to improve working processes and, at the same time, meet the needs of society. The points cited above serve to 
promote and stimulate skills in future professionals that allow them to create their own companies, adapted to new technologies and to the progress of science along with the development of the Colombian Caribbean region.

It is also to be considered that plans, programs and projects have been organized, because their promotion can contribute to economic and social development of countries. Hence, management dimensions were stipulated. These dimensions involved explicitly and in an organized manner different actors for the generation of environments that contribute to that culture, namely direction, academic, administrative and financial management along with community management ${ }^{4}$.

Focusing the study in the Colombian Caribbean, it is evident that Riohacha, Sincelejo, Monteria, Santa Marta and Valledupar are the five capitals of this region that are among the eight poorest of the country, according to the numbers provided by the Multidimensional and Monetary Poverty Report of the National Department of Statistics (DANE ${ }^{5}$ in Spanish).

The aforementioned study reveals that, although indicators of extreme poverty fell on the Caribbean coast, the cities of that region are still below Bogota, Cali, Medellin and Bucaramanga. In this regard, it was mentioned that Barranquilla and Cartagena are the capitals of the Colombian Caribbean that show better behavior, taking into account that they have aimed at the generation of knowledge considering science and technology as engines of value creation; unlike the rest of the cities that show a cracked formal institutionality with weak public policies, few sources of financing and few incentives.

DANE $^{5}$ reveals that, in the Caribbean, the city with the highest incidence of poverty is Riohacha with $43.3 \%$. Similarly, Monteria is the capital with the highest income inequality with a Gini coefficient of 0.538 (this coefficient measures how far the distribution of income between individuals or households moves away from a perfectly equitable distribution). On the other hand, the results of the DANE study establish that when analyzing the Multidimensional Poverty Index (IPM in Spanish), the Caribbean Coast is the second region with a greater percentage of poor people in the country: $37.4 \%$, exceeded by a minimum percentage only by the Pacific region (excluding the department of Valle del Cauca) with 37.6\%.

In accordance with the foregoing, Global Entrepreneurship Monitor, GEM ${ }^{6}$ conducted an analysis on the rates of new business activity, between the periods of 2010-2012. The main cities of the eight departments that make up the Caribbean Region were considered as central axis. Results showed that the most representative percentages were: Barranquilla: $24.6 \%$, followed by Cartagena (22\%), Sincelejo (20.4\%) and Santa Marta (20.3\%). However, according to experts in business creation issues surveyed by GEM, many improvements still need to be made.

Following the order of ideas, in non-systematized research, it was evident that among the main causes of the situation outlined above are: most of public universities in the Caribbean Coast do not include the subject Entrepreneurship in their academic syllabuses they offer. Additionally, those who indeed teach it do so out of schedule, with low intensity of hours. In this sense, issues related to the culture of entrepreneurship are developed in a fragmented and disconnected manner, as a result of the lack of a methodology that articulates content developed in various subjects. It is also evident the scarce offer of seminars and continuing education courses that could contribute to generate a new entrepreneurial culture in the future professionals.

On the other hand, it is clear that on the Colombian Caribbean coast, there has been a lack of political goodwill in order to encourage the culture of entrepreneurship. Although there is Law 1014 of $2006^{2}$, this law has not had the expected effects yet. Besides, there is little evidence on the identification and analysis of the factors that drive the individual decision to be an entrepreneur. In contrast, it is common to hear that universities prepare their students to be good employees and not to engender knowledge and innovative ideas that result into a new business unit which produces employment, economic development and sustainability.

Likewise, it should be pointed out that if this situation continues, the levels of social welfare, productivity, economic growth as well as competitiveness in the Colombian Caribbean Region will continue to decrease. Additionally, the country will be wasting some of its opportunities for progress. In this regard, it is necessary to educate to undertake, and at that point universities should configured as one of the protagonists for the consolidation of the Culture of Entrepreneurship as a way of life for the Region and the country.

\section{Materials and Methods}

The research was conceived as descriptive, analytical ${ }^{7}$, transectional and field-type. According to the study topic, 
it has a non-experimental design. The primary source of information was composed of seven directors and/ or coordinators of the different agencies responsible for promoting entrepreneurship in public universities in the departments belonging to the Colombian Caribbean Region (Table 1).

The technique of observation by survey was applied in order to collect information related to the variable. A Likert-scale ${ }^{8}$ questionnaire was designed and structured by items oriented to measure the behavior of the variable. In this way, the instrument was designed with closed questions which allow reaching the purpose of the present investigation, using Likert-type responses, represented by the precise alternatives of answers (Table 2).

The validity of the questionnaires was determined by expert judgments, while their reliability was calculated by the Cronbach's Alpha method, with a value of 0.92 ; resulting highly reliable. Data was processed according to descriptive statistics 9 .

Table 1. Characterization of the population

\begin{tabular}{|c|c|c|}
\hline $\begin{array}{l}\text { Element of the } \\
\text { population }\end{array}$ & Sampling units & Quantity \\
\hline $\begin{array}{l}\text { Universidad de } \\
\text { la Guajira }\end{array}$ & $\begin{array}{l}\text { EntrepreneurshipUnit } \\
\text { Principal }\end{array}$ & 1 \\
\hline $\begin{array}{l}\text { Universidad } \\
\text { Popular del } \\
\text { Cesar }\end{array}$ & $\begin{array}{l}\text { EntrepreneurshipUnit } \\
\text { Principal }\end{array}$ & 1 \\
\hline $\begin{array}{l}\text { Universidad del } \\
\text { Magdalena }\end{array}$ & $\begin{array}{l}\text { Center of Innovation and } \\
\text { Entrepreneurship Principal }\end{array}$ & 1 \\
\hline $\begin{array}{l}\text { Universidad del } \\
\text { Atlántico }\end{array}$ & $\begin{array}{l}\text { Entrepreneurship Program } \\
\text { Coordinator }\end{array}$ & 1 \\
\hline $\begin{array}{l}\text { Universidad de } \\
\text { Cartagena }\end{array}$ & $\begin{array}{l}\text { Enterprise Consulting Office } \\
\text { Coordinator }\end{array}$ & 1 \\
\hline $\begin{array}{l}\text { Universidad de } \\
\text { Sucre }\end{array}$ & $\begin{array}{l}\text { EntrepriseDevelopment } \\
\text { Center Principal }\end{array}$ & 1 \\
\hline $\begin{array}{l}\text { Universidad de } \\
\text { Córdoba }\end{array}$ & $\begin{array}{l}\text { Enterprise Development and } \\
\text { Technology Transfer Unit } \\
\text { Principal }\end{array}$ & 1 \\
\hline Total & & 7 \\
\hline
\end{tabular}

Tabla 2. Weighting of answers

\begin{tabular}{|l|l|}
\hline & Weighting \\
\hline Stronglyagree (SA) & 5 \\
\hline Agree (A) & 4 \\
\hline Neutral (N) & 3 \\
\hline Disagree (D) & 2 \\
\hline Stronglydisagree (SD) & 1 \\
\hline
\end{tabular}

\section{Results and Discussion}

After describing the results of Table 3, and according to the favorable results, it can be inferred that the Mandatory teaching indicator is the one that has a greater relevance for the population under study, which contrasts with the provisions of Law 1014 of $2016^{2}$, in which it is considered that training for entrepreneurship seeks the development of a culture with actions that generate training in basic skills, job skills, citizenship skills and business skills in public universities of the Colombian Caribbean Coast along with its articulation with the productive sector.

After describing the results of Table 4, and in accordance with the favorable results, it can be inferred that the Teaching indicator is the one that has a greater relevance for the population under study, which contrasts with the provisions of Law 1014 (2006: 1) $)^{2}$, which points out that public universities of the Colombian Caribbean Coast have established favorable environments for training and development of critical, ethically committed, expressive, self-aware people, with a sense of personal and social responsibility.

Instead, the Ministry of Education (MinEducacion ${ }^{3}$ in Spanish) highlights that public universities, in the departments belonging to the Colombian Caribbean region, must structure a curricular proposal focused on basic, investigative and citizen competence training, in different pedagogical contexts, which allows aligning programs, strategies and processes towards the development of entrepreneurial attitudes.

After describing the results of Table 5, and in accordance with the favorable results, it can be inferred that the Academic indicator is the one that has a greater relevance for the population under study. This contrasts with the considerations of the Ministry of Education ${ }^{4}$, which states that academic management is responsible for pedagogical and curricular actions to ensure the development of the necessary skills in students for their proper personal, social and professional performance, by implementing a curricular design, promotion of pedagogical practices that creates awareness in students about their leading role in the advancement of society.

\section{Conclusions}

It was concluded that it is mandatory to promote the entrepreneurial spirit in all public universities of the Colombian Caribbean Coast, which promotes and works jointly on the principles and values established by the 
Table 3. Percentage description of dimension: public policies fulfillment

\begin{tabular}{|c|c|c|c|c|c|c|c|c|c|c|c|c|c|}
\hline \multirow{3}{*}{ Indicator } & \multirow{3}{*}{ Item } & \multirow{2}{*}{\multicolumn{2}{|c|}{$\begin{array}{l}\text { SA } \\
5\end{array}$}} & \multirow{2}{*}{\multicolumn{2}{|c|}{ A }} & \multirow{2}{*}{\multicolumn{2}{|c|}{$\frac{N}{3}$}} & \multirow{2}{*}{\multicolumn{2}{|c|}{\begin{tabular}{|l|l} 
\\
2
\end{tabular}}} & \multirow{2}{*}{\multicolumn{2}{|c|}{ SD }} & \multirow{2}{*}{\multicolumn{2}{|c|}{ Totals }} \\
\hline & & & & & & & & & & & & & \\
\hline & & Af & Rf \% & Af & Rf \% & Af & Rf \% & Af & Rf \% & Af & Rf \% & Af & Rf \% \\
\hline \multirow{3}{*}{$\begin{array}{l}\text { Mandatory } \\
\text { teaching }\end{array}$} & $\begin{array}{l}\text { Training by competences is } \\
\text { articulated with the needs of the } \\
\text { environment. }\end{array}$ & 0 & $0 \%$ & 4 & $57 \%$ & 0 & $0 \%$ & 3 & $43 \%$ & 0 & $0 \%$ & 7 & $100 \%$ \\
\hline & $\begin{array}{l}\text { Students are able to create their } \\
\text { own company, adapting to new } \\
\text { technologies. }\end{array}$ & 3 & $43 \%$ & 4 & $57 \%$ & 0 & $0 \%$ & 0 & $0 \%$ & 0 & $0 \%$ & 7 & $100 \%$ \\
\hline & $\begin{array}{l}\text { The culture of entrepreneurship is } \\
\text { promoted in all levels. }\end{array}$ & 7 & $100 \%$ & 0 & $0 \%$ & 0 & $0 \%$ & 0 & $0 \%$ & 0 & $0 \%$ & 7 & $100 \%$ \\
\hline \multirow{3}{*}{$\begin{array}{l}\text { Promotion } \\
\text { and support } \\
\text { programs } \\
\text { for new } \\
\text { companies. }\end{array}$} & $\begin{array}{l}\text { Consultancy processes for } \\
\text { entrepreneurs are carried out. }\end{array}$ & 3 & $43 \%$ & 0 & $0 \%$ & 2 & $29 \%$ & 2 & $29 \%$ & 0 & $0 \%$ & 7 & $100 \%$ \\
\hline & $\begin{array}{l}\text { Orientation services for } \\
\text { formalization are offered. }\end{array}$ & 3 & $43 \%$ & 2 & $29 \%$ & 0 & $0 \%$ & 2 & $29 \%$ & 0 & $0 \%$ & 7 & $100 \%$ \\
\hline & $\begin{array}{l}\text { The entrepreneur has the facility to } \\
\text { trade his services. }\end{array}$ & 0 & $0 \%$ & 3 & $43 \%$ & 0 & $0 \%$ & 4 & $57 \%$ & 0 & $0 \%$ & 7 & $100 \%$ \\
\hline
\end{tabular}

Table 4. Percentage description of dimension: Missionary processes

\begin{tabular}{|c|c|c|c|c|c|c|c|c|c|c|c|c|c|}
\hline \multirow{3}{*}{ Indicator } & \multirow{3}{*}{ Item } & \multirow{2}{*}{\multicolumn{2}{|c|}{$\begin{array}{l}\text { SA } \\
5\end{array}$}} & \multirow{2}{*}{\multicolumn{2}{|c|}{\begin{tabular}{|l|}
$\mathbf{A}$ \\
4
\end{tabular}}} & \multirow{2}{*}{\multicolumn{2}{|c|}{\begin{tabular}{|l|}
$\mathbf{N}$ \\
3 \\
\end{tabular}}} & \multirow{2}{*}{\multicolumn{2}{|c|}{\begin{tabular}{|l|}
$\mathrm{D}$ \\
2
\end{tabular}}} & \multirow{2}{*}{\multicolumn{2}{|c|}{\begin{tabular}{|l|} 
SD \\
1 \\
\end{tabular}}} & \multirow{2}{*}{\multicolumn{2}{|c|}{ Totals }} \\
\hline & & & & & & & & & & & & & \\
\hline & & Af & Rf \% & Af & Rf \% & Af & Rf \% & Af & Rf \% & Af & Rf \% & Af & Rf \% \\
\hline \multirow{3}{*}{ Teaching } & $\begin{array}{l}\text { Curricular actions are structured to } \\
\text { teach entrepreneurship. }\end{array}$ & 5 & $71 \%$ & 2 & $29 \%$ & 0 & $0 \%$ & 0 & $0 \%$ & 0 & $0 \%$ & 7 & $100 \%$ \\
\hline & $\begin{array}{l}\text { Skills that are not part of the } \\
\text { personality of entrepreneurs can be } \\
\text { acquired through teaching. }\end{array}$ & 2 & $29 \%$ & 5 & $71 \%$ & 0 & $0 \%$ & 0 & $0 \%$ & 0 & $0 \%$ & 7 & $100 \%$ \\
\hline & $\begin{array}{l}\text { The culture of entrepreneurship is } \\
\text { evidenced in the pedagogical model. }\end{array}$ & 3 & $43 \%$ & 2 & $29 \%$ & 2 & $29 \%$ & 0 & $0 \%$ & 0 & $0 \%$ & 7 & $100 \%$ \\
\hline \multirow{3}{*}{ Research } & $\begin{array}{l}\text { Research projects oriented towards } \\
\text { a culture of entrepreneurship are } \\
\text { generated. }\end{array}$ & 3 & $43 \%$ & 2 & $29 \%$ & 2 & $29 \%$ & 0 & $0 \%$ & 0 & $0 \%$ & 7 & $100 \%$ \\
\hline & $\begin{array}{l}\text { Articles that present results of } \\
\text { scientific research on the subject of } \\
\text { entrepreneurship are conceived. }\end{array}$ & 0 & $0 \%$ & 5 & $71 \%$ & 2 & $29 \%$ & 0 & $0 \%$ & 0 & $0 \%$ & 7 & $100 \%$ \\
\hline & $\begin{array}{l}\text { It is established how culture of } \\
\text { entrepreneurship has impacted the } \\
\text { environment. }\end{array}$ & 0 & $0 \%$ & 5 & $71 \%$ & 0 & $0 \%$ & 2 & $29 \%$ & 0 & $0 \%$ & 7 & $100 \%$ \\
\hline \multirow{3}{*}{ Extension } & $\begin{array}{l}\text { Knowledge transfer is considered an } \\
\text { agent of innovation. }\end{array}$ & 0 & $0 \%$ & 3 & $43 \%$ & 4 & $57 \%$ & 0 & $0 \%$ & 0 & $0 \%$ & 7 & $100 \%$ \\
\hline & $\begin{array}{l}\text { Models that link it with the } \\
\text { productive sector are developed } \\
\text { in order to meet the needs of } \\
\text { organizations. }\end{array}$ & 3 & $43 \%$ & 4 & $57 \%$ & 0 & $0 \%$ & 0 & $0 \%$ & 0 & $0 \%$ & 7 & $100 \%$ \\
\hline & $\begin{array}{l}\text { Continuing education courses are } \\
\text { offered to meet the needs of the } \\
\text { productive sector. }\end{array}$ & 7 & $100 \%$ & 0 & $0 \%$ & 0 & $0 \%$ & 0 & $0 \%$ & 0 & $0 \%$ & 7 & $100 \%$ \\
\hline
\end{tabular}


Table 5. Percentage description of dimension: Dimensions of institutional management

\begin{tabular}{|c|c|c|c|c|c|c|c|c|c|c|c|c|c|}
\hline \multirow{3}{*}{ Indicator } & \multirow{3}{*}{ Item } & \multirow{2}{*}{\multicolumn{2}{|c|}{\begin{tabular}{|l|} 
SA \\
5 \\
\end{tabular}}} & \multirow{2}{*}{\multicolumn{2}{|c|}{\begin{tabular}{|l|} 
A \\
4 \\
\end{tabular}}} & \multirow{2}{*}{\multicolumn{2}{|c|}{$\frac{N}{3}$}} & \multirow{2}{*}{\multicolumn{2}{|c|}{\begin{tabular}{|l|} 
D \\
2 \\
\end{tabular}}} & \multirow{2}{*}{\multicolumn{2}{|c|}{$\begin{array}{l}\text { SD } \\
1 \\
\end{array}$}} & \multirow{2}{*}{\multicolumn{2}{|c|}{ Totals }} \\
\hline & & & & & & & & & & & & & \\
\hline & & Af & Rf \% & Af & $\mathrm{Rf} \%$ & Af & Rf \% & Af & Rf \% & Af & Rf \% & Af & Rf \% \\
\hline \multirow{3}{*}{ Direction } & $\begin{array}{l}\text { The PEI positions its image in } \\
\text { terms of management with clearly } \\
\text { differentiating elements. }\end{array}$ & 2 & $29 \%$ & 0 & $0 \%$ & 5 & $71 \%$ & 0 & $0 \%$ & 0 & $0 \%$ & 7 & $100 \%$ \\
\hline & $\begin{array}{l}\text { Projects aimed at boosting a } \\
\text { culture of entrepreneurship are } \\
\text { proposed. }\end{array}$ & 7 & $100 \%$ & 0 & $0 \%$ & 0 & $0 \%$ & 0 & $0 \%$ & 0 & $0 \%$ & 7 & $100 \%$ \\
\hline & $\begin{array}{l}\text { The generation of a culture } \\
\text { invigorates the ideals, values and } \\
\text { principles that identify it. }\end{array}$ & 3 & $43 \%$ & 2 & $29 \%$ & 2 & $29 \%$ & 0 & $0 \%$ & 0 & $0 \%$ & 7 & $100 \%$ \\
\hline \multirow{3}{*}{ Academic } & $\begin{array}{l}\text { Through the implementation of } \\
\text { pedagogical practices, students } \\
\text { are aware of their leading role in } \\
\text { changing their quality of life. }\end{array}$ & 3 & $43 \%$ & 4 & $57 \%$ & 0 & $0 \%$ & 0 & $0 \%$ & 0 & $0 \%$ & 7 & $100 \%$ \\
\hline & $\begin{array}{l}\text { A curricular proposal focused on } \\
\text { competence training is structured } \\
\text { by aligning the programs } \\
\text { towards the development of } \\
\text { entrepreneurial attitudes. }\end{array}$ & 0 & $0 \%$ & 7 & $100 \%$ & 0 & $0 \%$ & 0 & $0 \%$ & 0 & $0 \%$ & 7 & $100 \%$ \\
\hline & $\begin{array}{l}\text { Academic strategies towards the } \\
\text { development of entrepreneurial } \\
\text { attitudes are fulfilled. }\end{array}$ & 3 & $43 \%$ & 4 & $57 \%$ & 0 & $0 \%$ & 0 & $0 \%$ & 0 & $0 \%$ & 7 & $100 \%$ \\
\hline \multirow{3}{*}{$\begin{array}{l}\text { Administrative } \\
\text { and financial }\end{array}$} & $\begin{array}{l}\text { The adequate use of resources } \\
\text { generates habits in all the } \\
\text { members of the educational } \\
\text { community that show } \\
\text { entrepreneurial attitudes. }\end{array}$ & 3 & $43 \%$ & 2 & $29 \%$ & 0 & $0 \%$ & 2 & $29 \%$ & 0 & $0 \%$ & 7 & $100 \%$ \\
\hline & $\begin{array}{l}\text { Projects that involve the } \\
\text { community are generated by } \\
\text { optimizing the use of their } \\
\text { resources. }\end{array}$ & 5 & $71 \%$ & 0 & $0 \%$ & 2 & $29 \%$ & 0 & $0 \%$ & 0 & $0 \%$ & 7 & $100 \%$ \\
\hline & $\begin{array}{l}\text { The capacity for the use of } \\
\text { institutional resources is } \\
\text { strengthened. }\end{array}$ & 0 & $0 \%$ & 7 & $100 \%$ & 0 & $0 \%$ & 0 & $0 \%$ & 0 & $0 \%$ & 7 & $100 \%$ \\
\hline \multirow{3}{*}{$\begin{array}{l}\text { Of the } \\
\text { community }\end{array}$} & $\begin{array}{l}\text { Community actively participates } \\
\text { in the design of strategies } \\
\text { to promote the culture of } \\
\text { entrepreneurship. }\end{array}$ & 2 & $29 \%$ & 3 & $43 \%$ & 2 & $29 \%$ & 0 & $0 \%$ & 0 & $0 \%$ & 7 & $100 \%$ \\
\hline & $\begin{array}{l}\text { Inter-institutional agreements that } \\
\text { strengthen their relationship with } \\
\text { society are arranged. }\end{array}$ & 7 & $100 \%$ & 0 & $0 \%$ & 0 & $0 \%$ & 0 & $0 \%$ & 0 & $0 \%$ & 7 & $100 \%$ \\
\hline & $\begin{array}{l}\text { The educational community acts } \\
\text { as an articulating axis between the } \\
\text { institution and the environment. }\end{array}$ & 3 & $43 \%$ & 4 & $57 \%$ & 0 & $0 \%$ & 0 & $0 \%$ & 0 & $0 \%$ & 7 & $100 \%$ \\
\hline
\end{tabular}


Constitution, as stated in Law 1014 of 2016, which states that training for entrepreneurship seeks the development of a culture with actions that generate training in basic skills, job skills, citizenship skills and business skills along with the articulation with the productive sector.

It is also concluded that public universities in the departments pertaining to the Colombian Caribbean region must structure a curricular proposal focused on basic, investigative and citizen competence training in different pedagogical contexts, which allows organizing programs, strategies and processes towards the development of entrepreneurial attitudes. Hence, it is relevant to promote the entrepreneurship culture in public universities of the Colombian Caribbean Coast from the syllabus, in such a way that needs, interests as well as expectations present in the environment can be met, and so the compliance of personal, social and community life projects can be achieved.

Finally, it was determined that in order to promote the culture of entrepreneurship an Institutional Educational Project (PEI in Spanish) with vision and projection is required to anticipate changes, allows positioning an image in terms of management and results with clearly differentiating and significant elements. Likewise, it is necessary to execute control and evaluation actions, as well as adjustments to the processes, so that it will allow the use of information for the decision making. Similarly, the active participation of the institutional community in the processes of deliberation and consensus of the institutional horizon is important, in such a way that both needs and expectations about the generation of a culture of entrepreneurship materialize in concrete projects.

\section{References}

1. Cabana R, Cortes I, Plaza D, Castillo M, Alvarez A. Analisis de las capacidades potenciales y efectivas en alumnos de centros de educacion superior. Journal of Technology, Management \& Innovation. 2013; 9(4):1-10.

2. Diario Oficial de Colombia. Ley 1014 de Fomento a la Cultura de Emprendimiento. Congreso de la Republica de Colombia. 2006. Available from: http://www.secretariasenado.gov.co/senado/basedoc/ley_1014_2006.html. Date accessed: 26/08/2006.

3. Ministerio de Industria, Comercio y Turismo. Asociacion Colombiana de Universidades - ASCUN. Estado del arte sobre el emprendimiento universitario. Bogota D.C. 2014.

4. Ministerio de Educacion. La cultura del emprendimiento en Los establecimientos educativos. Orientaciones generales. Bogota D.C. 2012; 39:1-66.

5. Departamento Administrativo Nacional de Estadistica (DANE) (2012). Pobreza monetaria y multidimensional en Colombia. Boletin de prensa. Bogota, D.C. 2012:1-45.

6. GEM Colombia - Region Caribe 2012 - 2013. Global Entrepreneurship Monitor. Reporte Region Caribe. Universidad del Norte, Universidad de Cartagena. Fundacion Universitaria Tecnologico Comfenalco, Comfenalco Cartagena. 2013; p. 1-200.

7. Lopera J, Ramirez C, Zuluaga M, Ortiz J. El Metodo Analitico como metodo natural. Nomadas. Critical Journal of Social and Juridical Sciences. 2010; 25(1):1-28.

8. Hernandez R, Fernandez C, Baptista P. Metodologia de la Investigacion. $6^{\text {a }}$ Edicion Editorial McGraw Hill, Mexico D.F. 2014; p. 1-634.

9. Martinez C. Estadistica y muestreo. Ecoe Ediciones. 13a Edicion. Bogota D.C. 2012. p. 1-900. 